\title{
EL ARBITRIO DEL ENCUADRE: La simetría en las películas de Peter Greenaway
}

\author{
RAÚL YÉPEZ COLLANTES -YEPO
}

Fecha de recepción: 08/2016

Fecha de aceptación: 11/2016

\begin{abstract}
Resumen:
La simetría es un elemento clave en la concepción estética del encuadre cinematográfico, utilizado por Peter Greenaway en casi la totalidad de sus películas. Según Arlindo Machado "Toda síncopa del cuadro es una operación ideológicamente orientada, ya que entrar en campo o salir del campo presupone la intencionalidad de quien enuncia y la disponibilidad de quien es enunciado." Se intenta entonces, ensayar cierta interpretación de este recurso, aliado al uso de las técnicas implícitas en dicha acción. Además de revisar el concepto mismo de simetría, exploramos también, definiciones y significados conexos de encuadre y composición, bajo la óptica de autores clásicos involucrados con el concepto y la técnica de la fotografía y la cinematografía.
\end{abstract}

Palabras clave: Greenaway, Cinematografía, simetría, encuadre, composición.

\begin{abstract}
:
Symmetry is a key element for photography enclosing aesthetic conception, used by Peter Greenaway in most of his films. According to Arlindo Machado "All framing consists in an ideologically driven operation, as it goes in or out the field, and presumes the intention of whom speaks and the accessibility of whom is spoken." This article makes a reading of this source, joined to the use of procedures used for this action. Furthermore, the concept of symmetry, this text explores meanings and definitions related to framing and structure thought from classical authors point of view, including concepts like photography technique and cinematography.
\end{abstract}

Key words: Greenaway, Cinematography, symmetry, framing, composition.

\footnotetext{
Autor:

Msc. Arq. RAÚl YÉPEZ COLLANTES [YEPO] (Ibarra, Ecuador, 1968) Arquitecto por la Facultad de Arquitectura y Urbanismo de la Universidad Central del Ecuador, FAU-UC, Quito-Ecuador, 1987. Máster en Cultura Visual. Becario del gobierno brasileño mediante proceso selectivo (primer lugar) del Programa de Postgrado de la Universidad Federal de Goiás, FAV-UFG, Goiás-Brasil, 2010. Área de Concentración en Procesos y Sistemas Visuales. Docente universitario, fotógrafo profesional y artista investigador en el campo del lenguaje fotográfico. Ganador de varios concursos de fotografía. Ha presentado diversas exposiciones de fotografía desde el ańo 1988, hasta la actualidad (2016) dentro y fuera del país; impartido charlas sobre su trabajo creativo y participado en varias publicaciones.
} 


\section{Introducción:}

La simetría resulta ser un elemento clave en la concepción estética del encuadre cinematográfico, utilizado por Peter Greenaway en casi la totalidad de sus películas. Podemos constatar con cierto asombro, dentro del desarrollo de un mismo film, cómo la cámara por reiteradas ocasiones se ajusta a ese fin, aún a sabiendas, de que su percepción, requiere más de un intervalo puramente cinematográfico. Este recurso, incorporado ya en la poética del director británico riguroso y exigente, es aún más extraordinario, cuando no se limita a exhibir únicamente el escenario natural o construido, sino que además involucra la acción de los personajes.

El artificio compositivo de Greenaway, a veces condicionado a retóricas visuales, y a veces libre de ellas, podría dar pie a la elucubración más natural, diciendo que no hay nada tan restringido, desde el punto de vista de la acción, que un encuadre simétrico. Eso, porque en la intención hay una secuencia predeterminada, debido a la obligatoriedad de incorporar elementos similares, en el lado opuesto del eje. Sin embargo, vemos que a base de una repetición el elemento creativo cuenta. No en vano se desliza suavemente la imagen, en el lento acomodo de la cámara, hasta coincidir perfectamente con los límites precisos. Hay un enunciado en juego, algo para decir o dejar de decir... Inminentemente el aparato cinematográfico es un protagonista más, se acoge al orden, a la proporción, al equilibrio, al balance ejecutor de múltiples visualidades, hasta encontrar en el efecto reflejo, el instante decisivo $^{1}$ del encuadre.

1 El término "instante decisivo" está acuñado por algunos traductores para describir la principal característica de la obra fotográfica de Henri Cartier-Bresson.
En esa secuencia casi gravitacional, aparecen, bajo un ritual solemne y elegante, una lista interminable de detalles que pueden ser percibidos únicamente en el proceso de contemplación. Y para ello precisamente, para que ese proceso se ejecute, debe ocurrir lo inesperado, al menos desde el lenguaje fílmico habitual, la evidencia contundente de la cámara recorriendo lentamente el escenario, hasta finalmente detenerse en la simetría llenando toda la pantalla. Consecuentemente el encuadre, artificiosamente calculado en fracciones de segundo, resulta ser explícitamente geométrico y absolutamente impecable.

La referencia al proceso de contemplación establece de alguna manera la distinción entre la imagen en movimiento, característica fundamental del lenguaje cinematográfico y la imagen fija, como particularidad esencial del lenguaje fotográfico. Se entiende que a través de la fotografía se ejecuta con mayor efectividad el recogimiento visual, aquella opción que ofrece al espectador la posibilidad de quedarse examinando cada detalle de la imagen, hasta conectarse efectivamente con su aura ${ }^{2}$. Sin embargo, esto no ocurre usualmente en el cine. Algunas cualidades del montaje podrían pasar inadvertidas, debido a la vertiginosa concatenación de cuadros que superponen las imágenes en movimiento. Ocurre frecuentemente que asistiendo por segunda o tercera vez un film, descubrimos varios pormenores que fueron pensados por el director y que en la primera vez se nos pasaron desapercibidos.

Parar el ritmo en un marco compositivo

2 Copio textualmente el significado de aura descrito por Benjamin: "Pero ¿qué es propiamente el aura? Una trama muy especial de espacio y tiempo: la irrepetible aparición de una lejanía, por cerca que pueda encontrarse." (Benjamin, 2008:40). 
simétrico y equilibrado podría ser la estrategia para proveer al espectador del instante contemplativo. Eso es lo que hace Greenaway en sus películas. Trataremos de profundizar sobre esto en el análisis interpretativo, por ahora, coloquemos el recurso simétrico y sus conexos, encuadre y composición, en el ámbito de las definiciones. Hemos considerado, tratar cada uno de ellos, en los campos estrictos de la visualidad ligada a la imagen fotográfica y cinematográfica.

\section{Algunas consideraciones sobre la simetría:}

La concepción estética del encuadre cinematográfico, basado en el uso de la composición visual simétrica, que Greenaway expone en la mayoría de sus películas, nos abre algunos elementos de análisis. El punto de partida, desde luego, debería explorar lo que entendemos realmente por simetría. Tomemos en cuenta antes de nada, que el recurso no está ideado específicamente para la cinematografía. Digamos también por simple y obvia añadidura, que su estructura forma parte de las características de la naturaleza y que en la historia, sobran ejemplos del uso de la simetría aplicada a varios campos de las ciencias y de las artes.

El tema es más antiguo de lo que parece, las "leyes de la simetría" y los misterios de las proporciones, fueron ya exhaustivamente develados en el famoso tratado De Architectura, escrito por Vitruvio, nada menos que en los primeros años del siglo I a. C. Cabe señalar entre paréntesis, que, en el caso específico del director que nos ocupa, la utilización del encuadre simétrico, se configura con frecuencia, en un marco compositivo compuesto de escenarios naturales o construidos que ya poseen de antemano esta propiedad, o fueron previamente seleccionados debido a sus cualidades proporcionales.

Para entender del modo más sencillo el significado de simetría probablemente debamos visualizar la estructura geométrica de las figuras básicas (cuadrado, triángulo equilátero y círculo) y revisar el concepto de proporción, asuntos de los que se ocupan, con cierta especificidad, los fundamentos del diseño. Recurramos en este sentido, al documento docente titulado "Formas y Organizaciones Bidimensionales". Allí encontramos, asociada al capítulo sobre la Geometría de las Formas, una definición muy clara: "La simetría es un concepto que se aplica a las figuras para concebir un ordenamiento interno y externo de sus elementos en función de lograr su equilibrio axial" (Mogrovejo, 2000, p. 14).

Complementariamente, en el mismo documento mencionado, el concepto de proporción, en cambio, pertenece a los elementos determinantes de la forma y lo describe así: "En una forma cualesquiera, la proporción se expresa como la relación dimensional de las partes entre sí, y de las partes con el todo" (Mogrovejo, 2000, p. 9). Por consiguiente, hay dos elementos clave que deben subrayarse: Por un lado, la presencia indefectible de un eje, una línea imaginaria que divide el espacio compositivo en partes iguales, dejando ver de cada lado dos imágenes similares, en donde la una es la copia reflejada de la otra. $Y$ luego, el efecto resultante y manifiesto: un inequívoco equilibrio visual.

Tomemos en cuenta que nos estamos refiriendo al efecto que es observado dentro del espacio determinado por el ángulo del objetivo de la cámara, conocido en términos técnicos como "campo visual". El área que, en definitiva, presencia el espectador en la pantalla de proyección durante el tiempo determinado 


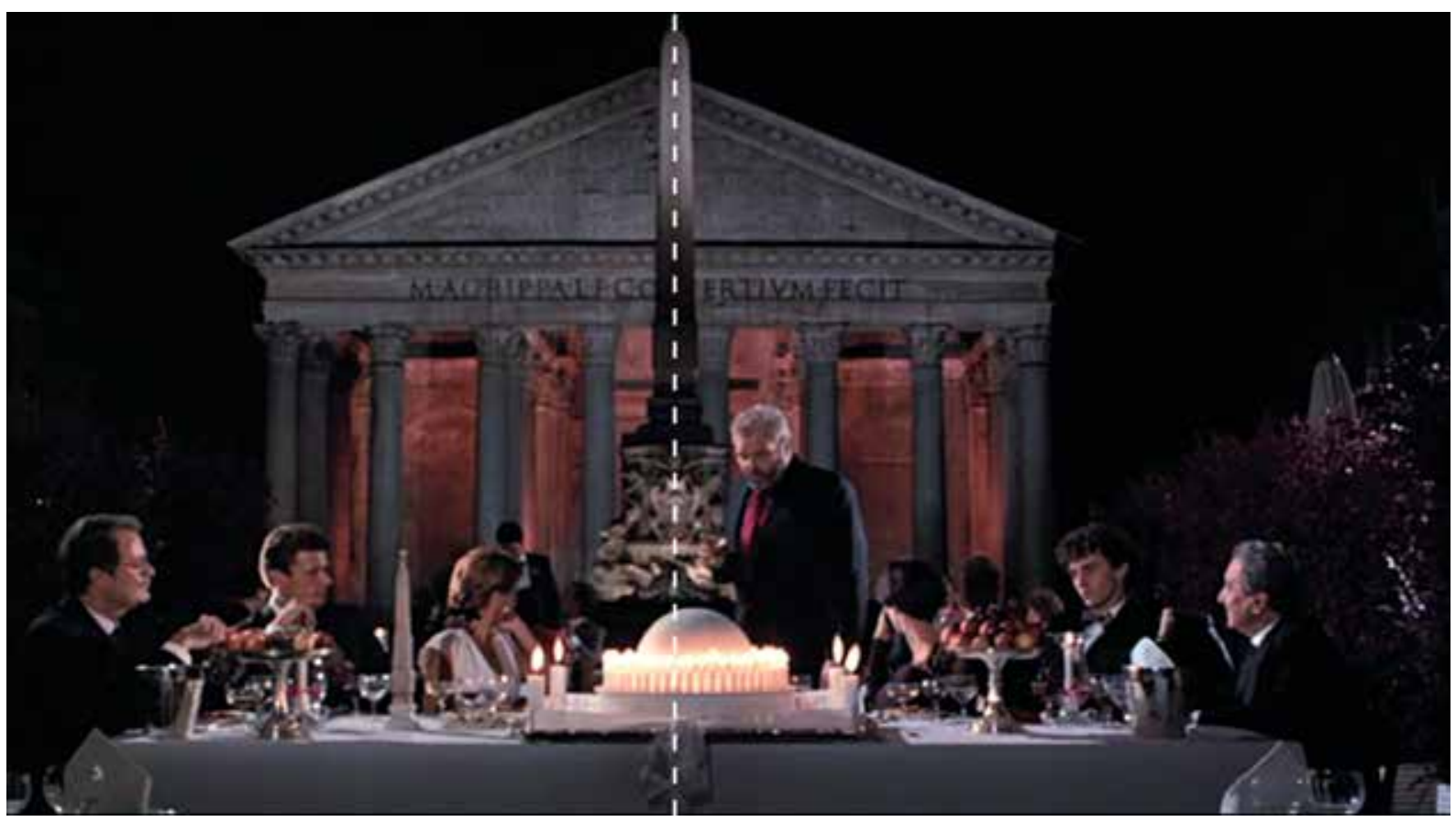

Figura 1: Escena de la película "El vientre del Arquitecto", minuto 05:16

GREENAWAY, Peter. The belly of an architect. Largometraje de 108 min. Reino Unido, 1987

por la acción. Ahora, no debemos olvidar que este espacio puede ampliarse o reducirse. Sabemos que accionando el anillo de distancia focal del objetivo, el ángulo de cobertura visual varía. Sorprende de algún modo, descubrir que Greenaway saca partido incluso de esta particularidad, cuando observamos, el zoom recorrer desde un gran angular hasta un closeup sin comprometer en lo más mínimo el eje simétrico del cuadro.

Si volviésemos la mirada a los conceptos elementales de la cinematografía, podríamos referirnos a que Greenaway elige la simetría para incursionar dentro del espacio geográfico, que habla del lugar, del continente de la acción. Es propiamente el escenario que acoge el complemento conocido como espacio dramático, el expresivo de la situación y en el que se involucran los personajes. Solo que esta vez, el continente no es puramente descriptivo, hay algo de magia en la selección del escenario, cumple un propósito inconmensurable: sumergir al espectador en lo que podría llamarse como sinestesia visual, la propiedad de un estímulo que se origina en el continente pero que afecta a un sentido diferente en el contenido.

\section{El arbitrio del encuadre:}

Y así, sin proponérnoslo, hemos estado ya, de una u otra manera, refiriéndonos al encuadre. Topemos entonces el tema con mayor detenimiento. En términos de la visualidad, encuadrar significa seleccionar una serie de elementos y colocarlos dentro de ciertos límites que en este caso, como queda dicho, se ajustan a los establecidos por el ángulo de cobertura visual del lente de la cámara. Este ejercicio, por supuesto, está libre de toda ingenuidad, toda vez que lo que se ha decidido mostrar está previamente pensado en el guion. Si detuviésemos un cuadro hasta obtener una 
imagen fija, diremos conforme lo hace Arlindo Machado refiriéndose a la fotografía, que "sea cual fuere el referente que la motiva, es siempre un rectángulo que recorta lo visible” (Machado, 1984, p. 76).

Viéndolo así de sencillo, el acto de encuadrar resulta obvio, pero en realidad en él, están implícitos asuntos más complejos. Debido a la coyuntura sobre el tema, no obstante se enfoque en la fotografía, vale la pena traer a colación un documento que en su época despertó curiosidad. Asumimos que cine y foto utilizan un lenguaje con la misma raíz en el que media necesariamente la utilización de una cámara. En el año 1985 el filósofo checo Vilém Flusser, publica un libro titulado Filosofia da caixa preta (podría traducirse como "filosofía de la cámara oscura”), en el cual se anota lo siguiente: “... la filosofía de la fotografía es necesaria porque, plantea una reflexión sobre las posibilidades de vivir libremente en un mundo programado por aparatos" (Flusser, 1985, p. 41). Esta postura arrancó de raíz algunos gestos heredados del pictorialismo ${ }^{3}$, en cuanto, otorgaban al aparato fotográfico una excepcional autonomía y las imágenes, se ajustaban a los patrones establecidos por las corrientes pictóricas de la época.

El enunciado sirvió para tomar

3 El pictorialismo surge a finales del siglo XIX a partir de algunos debates y teorías en torno de la fotografía como arte. Comenzando por Inglaterra, Francia y Estados Unidos, él se expande y permanece en auge durante el período entre los años 1890 y 1914. Fue un movimiento que reunió fotógrafos disconformes con la visión de la fotografía como mero registro de la realidad y que, aspiraban producir imágenes fotográficas que fuesen reconocidas como arte, buscando superar el aspecto mimético y documental de ese medio a través de la imitación de los patrones y de la estética de la pintura en boga en la segunda mitad del siglo XIX, especialmente el romanticismo, el realismo y el impresionismo (Vasconcelos, 2008, p.71). conciencia de la importancia del individuo que se coloca detrás de la cámara. A partir de entonces, se pudo entender que una ligera variación subjetiva, de milímetros en el encuadre, puede modificar la construcción de sentido de la imagen. A eso se refiere Machado cuando afirma que:
El cuadro de la cámara es una especie de tijera que recorta aquello que debe ser valorizado, que separa lo que es importante para los intereses de la enunciación de lo que es accesorio, que establece en seguida una primera organización de las cosas visibles. Eisenstein ya afirmó más de una vez que la visión figurativa es siempre una visión en "primer plano" (en el sentido en que se habla en primer plano en el cine, como detalle ampliado), porque tanto el pintor como el fotógrafo necesitan siempre efectuar una selección, para recortar en la continuidad del mundo, el campo significante que les interesa. (Machado, 1984, p. 76 - traducción del autor).

Cada selección a la hora de encuadrar es importante y trascendente, porque hay una responsabilidad de doble vía, por un lado el director de fotografía incluyendo en el campo lo que ha resuelto visibilizar y por otro el lectorespectador, recibiendo el mensaje desde su propia percepción. En cualquier caso, tenemos la conciencia plena de que emisor y receptor están siempre en continua interacción. Es ésta, con toda seguridad, otra más de las tantas razones por las que el encuadre interviene activamente en la construcción de sentido de la imagen cinematográfica. 
Si hemos hablado de límites, de recorte, de cuadro, es porque precisamente encuadrar implica poner en contraposición dos elementos relativamente complementarios: De la misma forma que hay un espacio visible, hay otro en cambio que por alguna razón y siempre, por alguna razón, ha sido destinado a la invisibilidad. Se produce, por tanto, en algún momento del encuadre, un proceso de descontextualización, que deja de lado todo aquello que no se ha hecho acreedor del privilegio de salir a la luz. Es el poder clasificatorio en manos de una persona, hacer ver lo que quiero que el espectador vea, el imperio de la imagen, el arbitrio del encuadre... "Evidentemente, esa selección, ese recorte no son nunca inocentes, ni gratuitos. Toda síncopa del cuadro es una operación ideológicamente orientada, ya que entrar en campo o salir de campo presupone la intencionalidad de quien enuncia y la disponibilidad del que es enunciado" (Machado, 1984, p. 77).

Nos provoca preguntarnos en este punto: ¿Cuál será la intencionalidad de Greenaway al incluir en el encuadre la simetría? ¿Y qué con su ideología? A nuestro modo de ver no hay una sola respuesta, existe una por cada instante simétrico, que se liga a su vez, con el problema planteado y con la actitud del personaje. Eso lo veremos con imágenes. Por ahora completemos los conceptos y entremos directamente a tratar sobre la composición.

\section{Componer para mostrar...}

De la composición nos entusiasma su estructura unificadora, su vocación por el orden y su capacidad de síntesis. Partimos de la existencia de varios elementos dispersos pero relacionados entre sí, a los que hay que organizar en función de un cometido. Cada uno de estos elementos, con sus propias características, deberán colocarse siguiendo pautas estructurales bien marcadas, con el objeto de que sin anularse se constituyan en un todo. Henri Cartier-Bresson decía que la composición es una "coalición simultánea, la coordinación orgánica de elementos visuales. No se compone gratuitamente, se precisa de entrada, tener la necesidad de ello y no se puede separar el fondo de la forma" (Cartier-Bresson, 2003, p. 24).

Con la idea de concentrarse en lo esencial, Néstor Almendros, por su parte y desde la visión del director de fotografía, en su libro "Días de una cámara”, asegura que todos poseemos, en mayor o menor medida, el sentido innato de la composición. De acuerdo con él: "Obtener una buena composición dentro de un encuadre cinematográfico es, en fin de cuentas, organizar sus distintos elementos visuales de manera que el todo sea inteligible, útil a la narración y, por lo tanto, agradable a la vista". (Almendros, 1983, p. 22).

Intentando profundizar aún más sobre el tema nos encontramos hurgando en los escritos de Serguei Eisenstein. Sus tratados sobre El sentido del cine y La forma del cine, se constituyen en los más valiosos legados de la literatura clásica sobre la técnica, estética y filosofía del cine. Como podremos imaginarnos, tiene un extenso, complejo y completo capítulo sobre los problemas de la composición cinematográfica. Trata el tema además en forma previa, en el acápite sobre estructura cinematográfica, del cual reproducimos lo siguiente que juzgamos oportuno para nuestro análisis:

Aun en los casos menos complicados es perfectamente evidente lo que nutre a la composición y de dónde deriva su experiencia y su material: la composición toma los elementos estructurales de los 
fenómenos gráficamente representados.

$\mathrm{Y}$ de esto compone su canon para la construcción del trabajo contenido.

Al realizar esta composición toma realmente elementos semejantes, primero que todo, de la estructura del comportamiento emocional del hombre, unido con el contenido experimentado de este o aquel fenómeno representado gráficamente.

Es por esta razón que la composición verdadera sea invariablemente profundamente bumana... (Eisenstein, 1967, p. 278)

Nótese la referencia al "comportamiento emocional del hombre" un detalle que es subrayado en la cita como elemento estructural de la imagen. Es de este modo que la acción de los personajes, su actitud frente al evento e incluso, su postura y movimiento se ven involucrados en la composición. De esas relaciones generando vínculos $\mathrm{y}$ de esos elementos estructurales contenidos y ordenados en el marco compositivo obtendremos una posible interpretación de cada momento simétrico exhibido por Greenaway en sus películas.

\section{El análisis interpretativo:}

Sabemos que no es tarea sencilla desentrañar la intención que el director británico asume al mostrar simetrías en la estructura dramatúrgica de sus films. Quizás, podamos sondear un argumento inicial respondiendo la siguiente interrogante: ¿Es un recurso estrictamente estético o se instala como corolario de una ideología implícita en el contenido? De lo que hemos dicho con anterioridad en concordancia con Machado, asumimos que la acción presupone una intencionalidad y tiene inmersa una ideología. Así lo entendemos en primera instancia conforme nos ilustra Greenaway en una entrevista con Eric Libiot:
Me interesa el orden, la simetría, la construcción matemática, y amo transferir sus principios al cine. Si uno considera cualquier secuencia del film como un número -usemos el ejemplo clásico de uno a diez-, se puede invertir el orden y partir del diez, o alternar los números pares con los impares. Ya ensayé utilizar esos grandes sistemas universales que son los números, el alfabeto y los colores. Amo ese género de contraposiciones porque permite una libertad artística muy grande. Y además, las matemáticas son una escritura más que un lenguaje. Estoy muy apegado a la noción de escritura universal

(Entrevista por Eric Libiot: http:// www.taringa.net/posts/tv-peliculasseries/1868106/Entrevista-a-petergreenaway.html.)

Mencionado en: "El Contrato del Dibujante". José María Sorando Muzás. http://catedu.es/matematicas_ mundo/CINE/cine_contrato.htm).

Encuadrar con equilibrio y balance implica para Greenaway un apego a los "sistemas universales" dentro de los cuales las matemáticas están exentas de lenguaje alguno. Él encuentra libertad artística en el orden y prefiere alternar la secuencia de escenas para vigorizar la estructura fílmica. Ilustraremos aquello más adelante, con imágenes extraídas de uno de sus filmes. Pero, no es esto únicamente lo que el director pretende, la propuesta explora otros argumentos adicionales armados en la propia secuencia escénica y en la misma composición simétrica.

Estos otros argumentos dan pie para una segunda instancia interpretativa que parte de tener en cuenta el hecho de que, toda imagen cinematográfica es una imagen técnica 
y en tal virtud se ajusta a los elementos que devienen del dicho recurso. Cabría examinar cómo los diferentes ajustes de ángulo de toma y profundidad de campo, por ejemplo, contribuyen a modificar la construcción de sentido de una imagen. Sin embargo, nos limitaremos a situarnos en los conceptos estudiados para extraer de ellos las particularidades del encuadre y el uso del puro recurso compositivo, aquel que resulta de colocar la cámara en un determinado espacio escénico o, mejor dicho, de colocar todos los elementos de la escena en un lugar específico y premeditado.

Aunque cerraremos el artículo proponiendo algunas conclusiones, es importante recalcar en que, debido a la extensa y compleja filmografía que ostenta este director británico, es casi imposible sistematizar el fenómeno en una sola tesis. En Greenaway no aplica la síntesis ni la unidad, cada instante simétrico tiene su propia interpretación.

Veámoslo entonces con las imágenes de un film, ellas resultan contundentes. Escoger una película de entre la extensa filmografía de Greenaway ya es una tarea compleja, por eso hemos preferido operar a la inversa. Por cualquier razón que sea, la película que tomaremos como ejemplo, The belly of an architect (1987) nos ha escogido a nosotros... En orden cronológico iremos mostrando algunas imágenes congeladas de dicha película incluyendo al pie de cada una, ciertos comentarios y citas que configuran el modelo interpretativo. Dejamos en ocasiones la pura muestra del encuadre con el dibujo en línea punteada del eje de simetría, para una libre y abierta interpretación a cargo del lector. En definitiva, este ejercicio no pretende de modo alguno ser más que un sondeo subjetivo y sintomático:

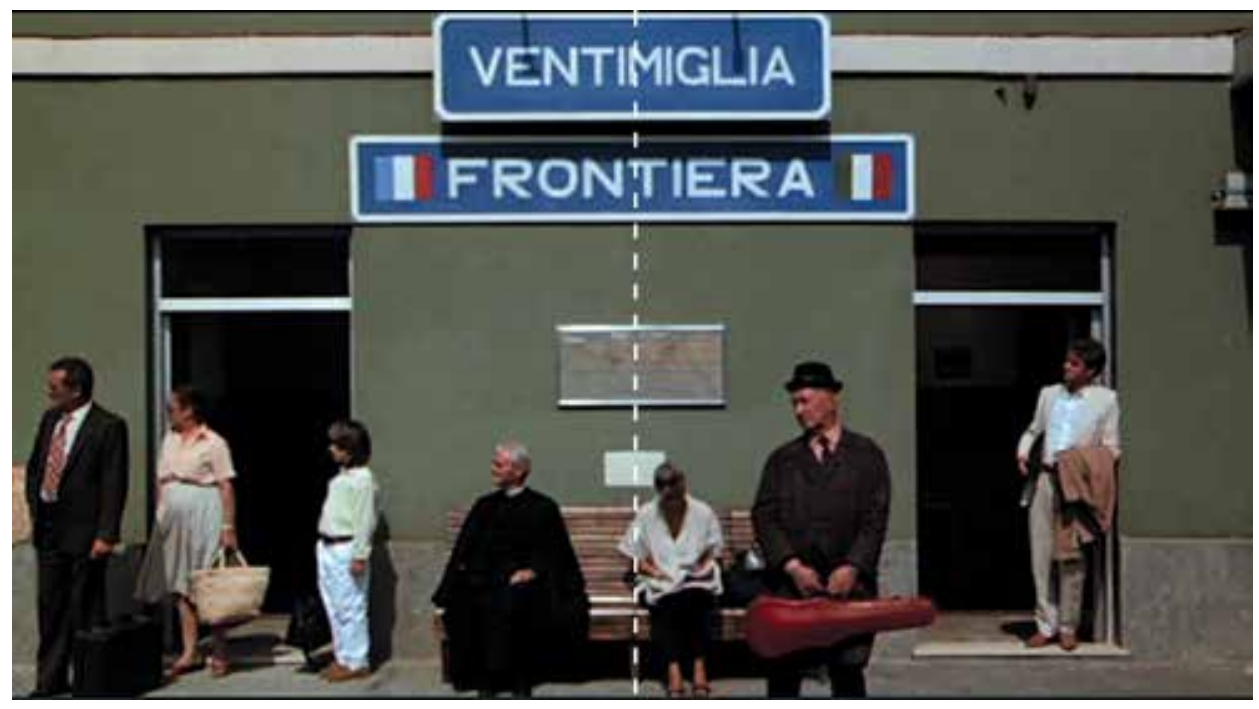

Figura 2: minuto 01:25

Primera imagen marcadamente simétrica del film. Expectativa en los personajes. Aparentemente el tren deberá detenerse; sin embargo, pasa velozmente por el frente de la estación. Aunque se muestra la gente esperando, el paso del tren no altera su impavidez e indiferencia. La composición muestra un encuadre evidentemente simétrico, pero algo desbalanceado debido a una mayor cantidad de gente en el cuadrante de la izquierda. 


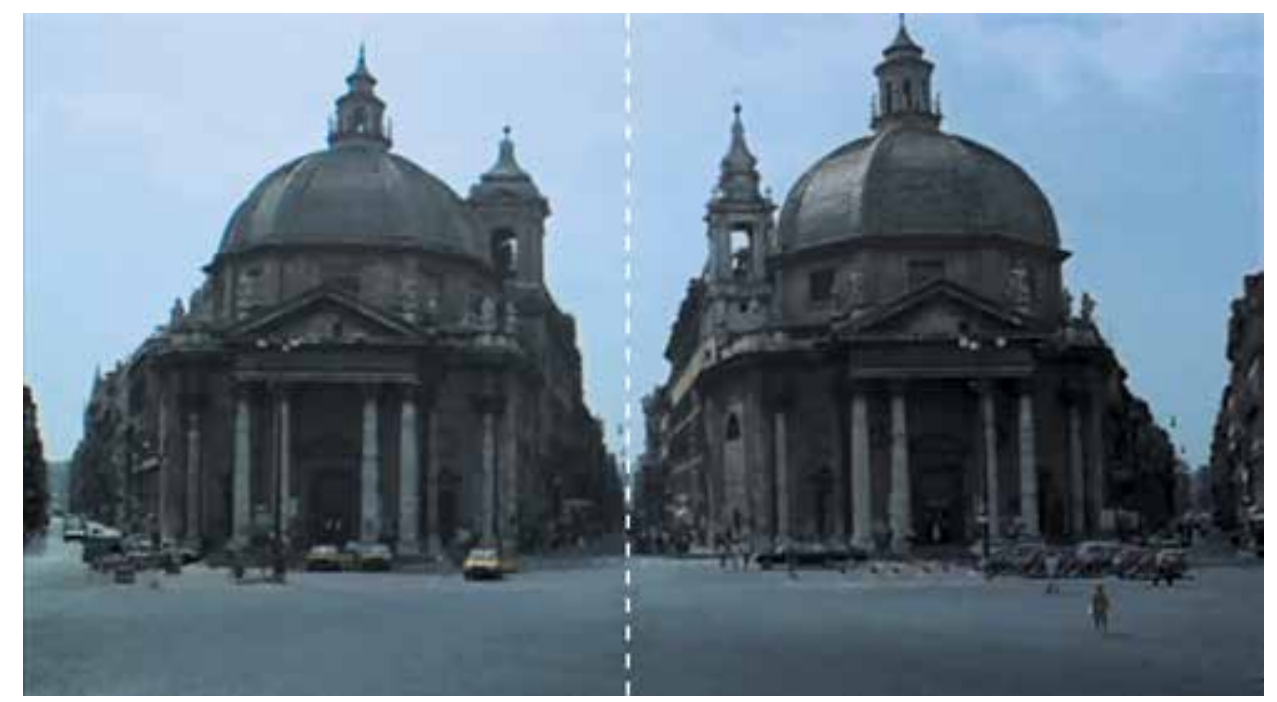

Figura 3: minuto 03:01

El arribo a la ciudad, Roma en todo su esplendor. Hay referencias a la escala monumental, se incluyen personas y vehículos para establecer comparaciones. La perspectiva con fuga en el fondo inferior relata la situación inicial, los monumentos de base sólida. Al momento se presume una estabilidad emocional del personaje principal, el arquitecto estadounidense Stourley Kracklite (interpretado por Brian Dennehy).

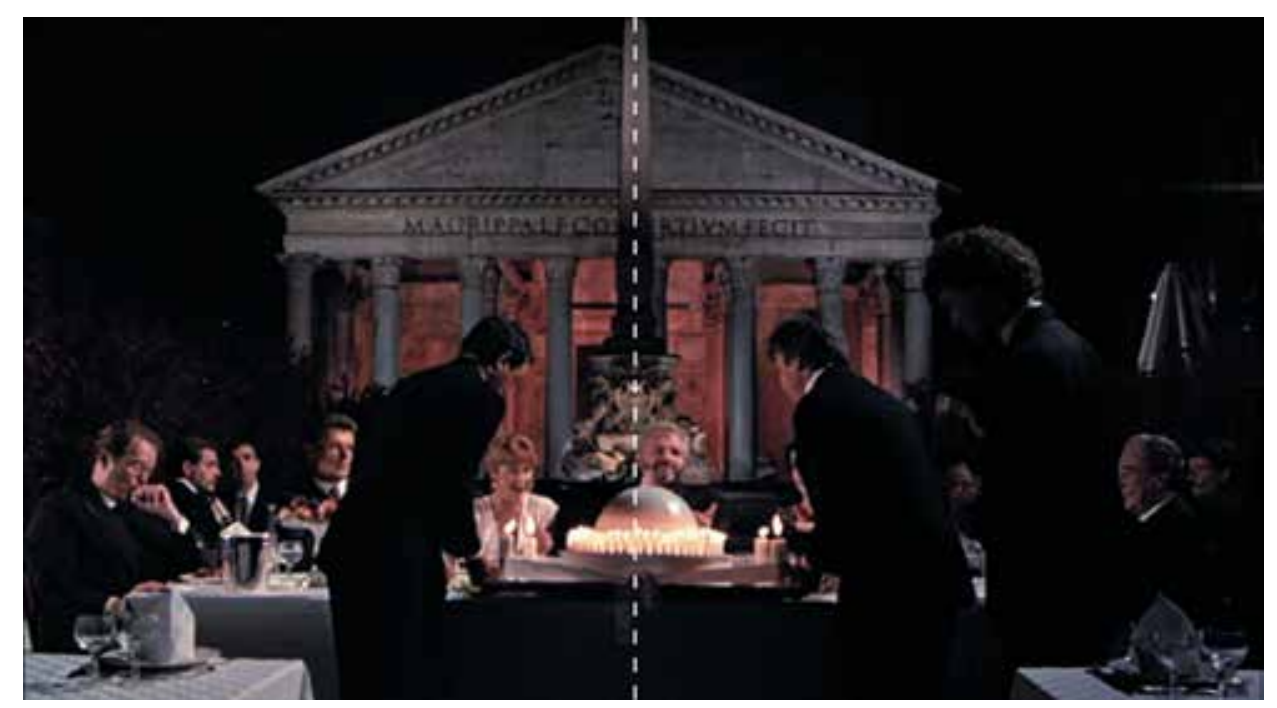

Figura 4: minuto 04:08

Kracklite preside la inauguración de la exposición dedicada al arquitecto francés del siglo XVIII Étienne-Louis Boullée. Aunque la cámara está en movimiento, sorprende como el obelisco que se mira en la parte posterior, se mantiene todo el tiempo en el eje central, hasta detenerse en la composición perfectamente simétrica. Quien preside es colocado en el centro, el eje simétrico le otorga jerarquía al personaje. 


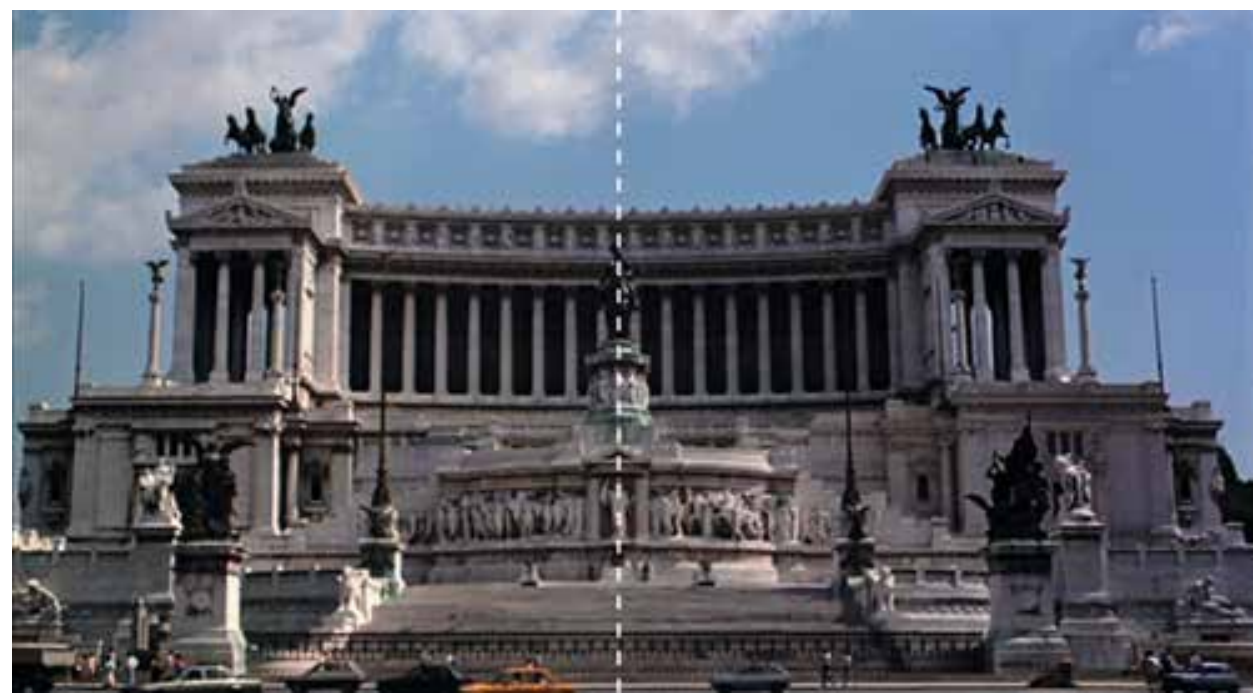

Figura 5: minuto 15:16

El marco de los monumentos patrimoniales de Roma, redunda en el mensaje, no es simétrica únicamente la composición, también el edificio lo es. "Tal posibilidad de repetición es lo que contribuye ante todo a dar una sensación de unidad" (Eisenstein, 1967, p. 386).

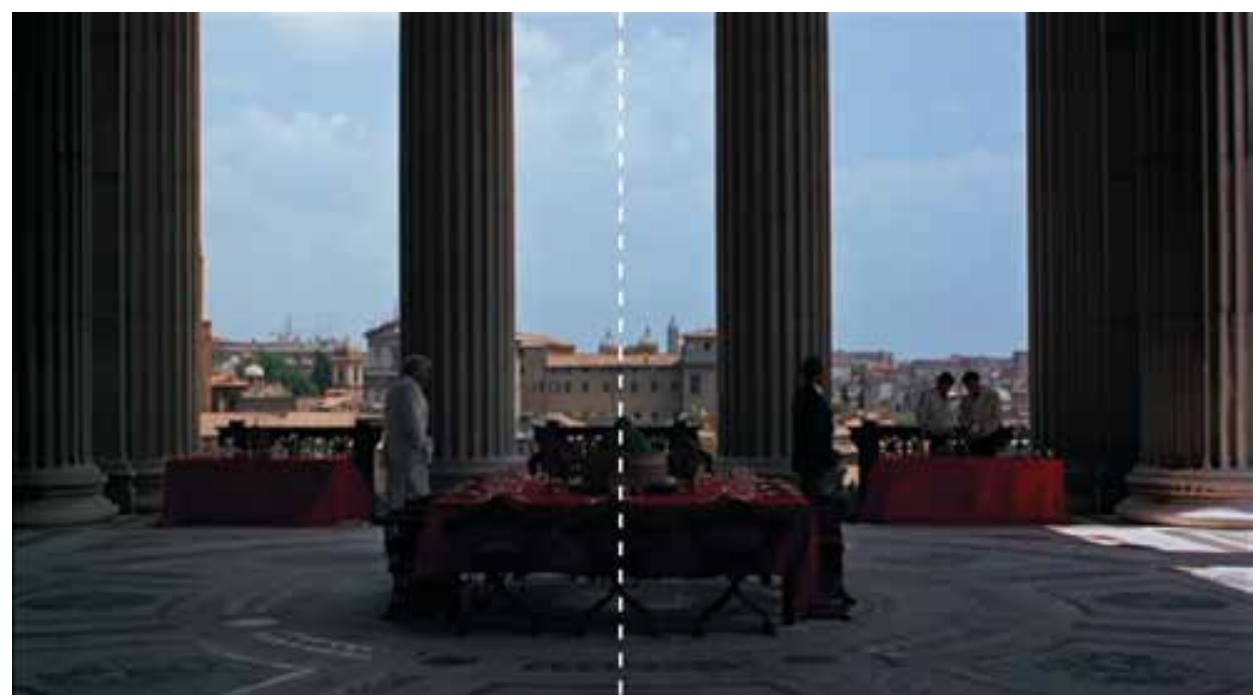

Figura 6: minuto 15:20

Insinuación dicotómica. Interior-exterior. Doble magnificencia monumental. Fondo de la ciudad, doble marco conceptual. El personaje se ve minimizado por el gran espacio escénico en el que se desarrolla la acción, un elemento premonitorio de la crisis venidera... 


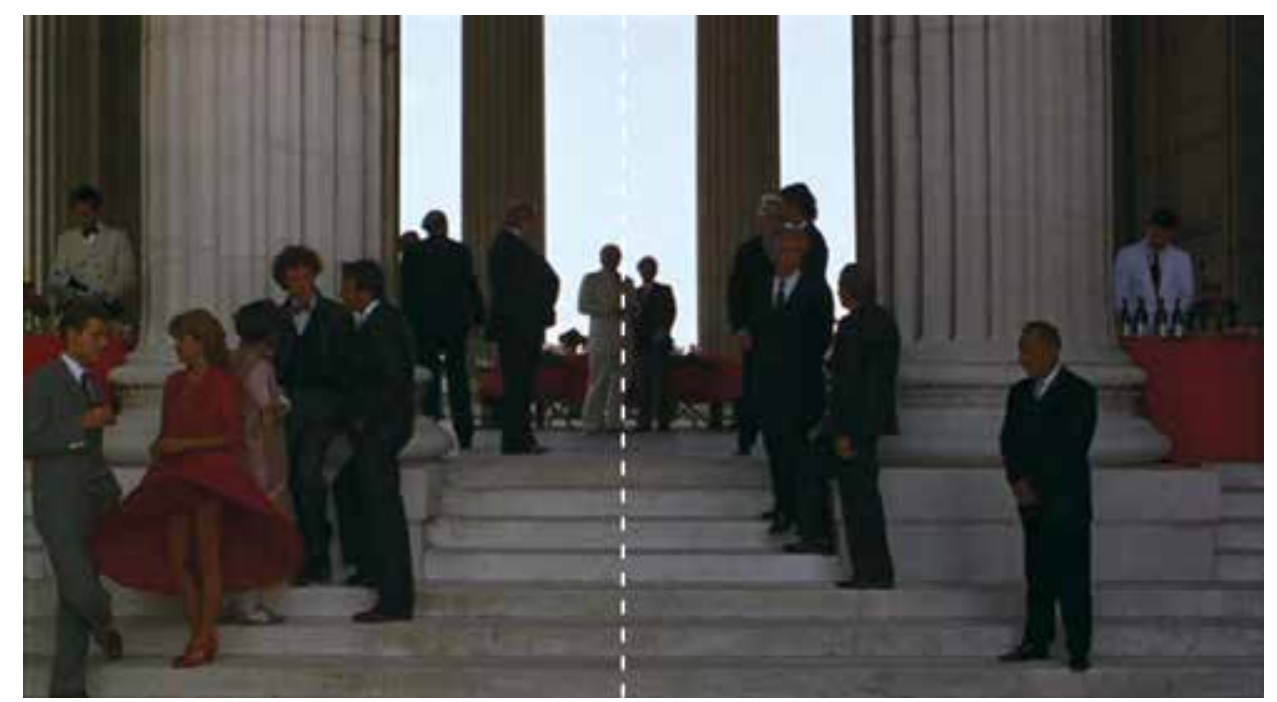

Figura 7: minuto 15:31

Resalta la distribución de los personajes, aparentemente relajada y espontánea, colocados en el cuadro, incentivando la perspectiva y dirigiendo la mirada al personaje principal como una flecha. Hay cierta indiferencia entre los asistentes; sin embargo, se advierten ciertos nexos peligrosos. Nótese el uso del color como elemento simbólico. Hay un diálogo entre el vestuario y el escenario.

Kracklite, viste de blanco, en cuanto que su esposa de rojo. Lo blanco es lo rígido, lo sólido, lo inamovible, mientras que el rojo representa lo vulnerable, lo ligero, lo transitorio... las telas de los manteles y el vestido se mueven con el viento...

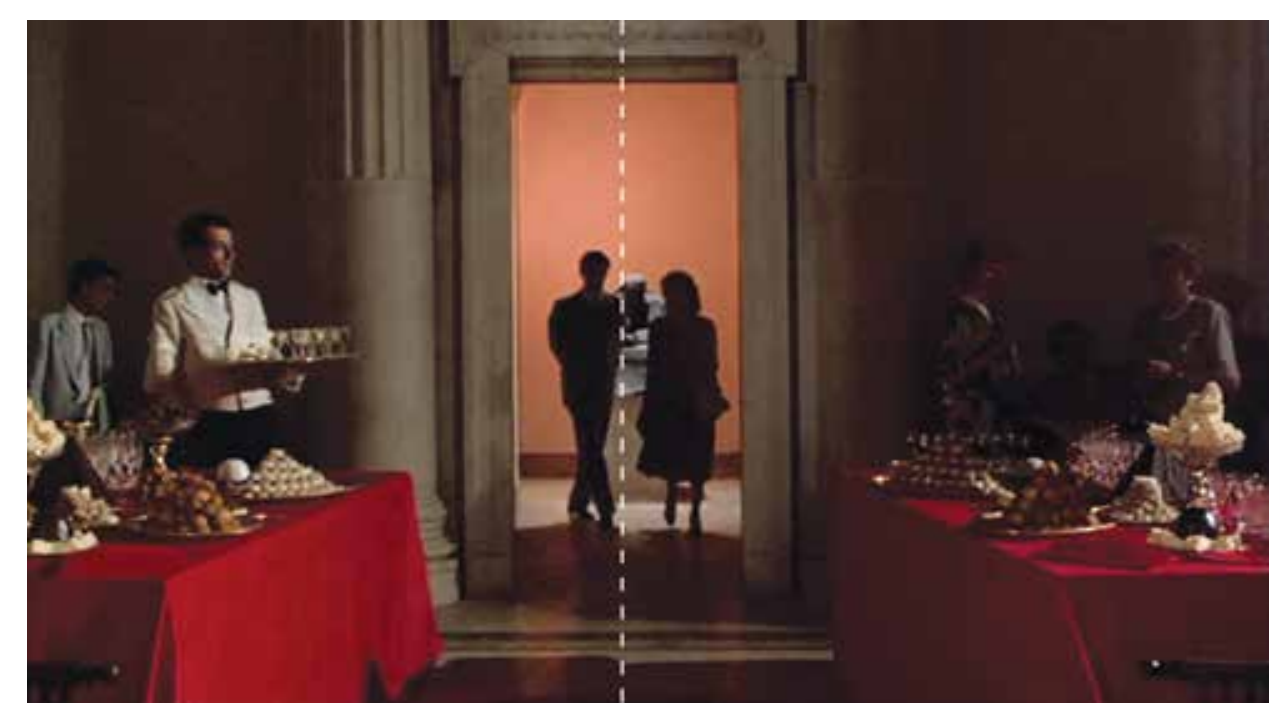

Figura 8: minuto 16:09

Exposición del criterio de centralidad. Todo conduce a la acción a pesar de no estar definidos los personajes sino a través únicamente de las siluetas. Hay en juego el inicio de una relación ilícita. 


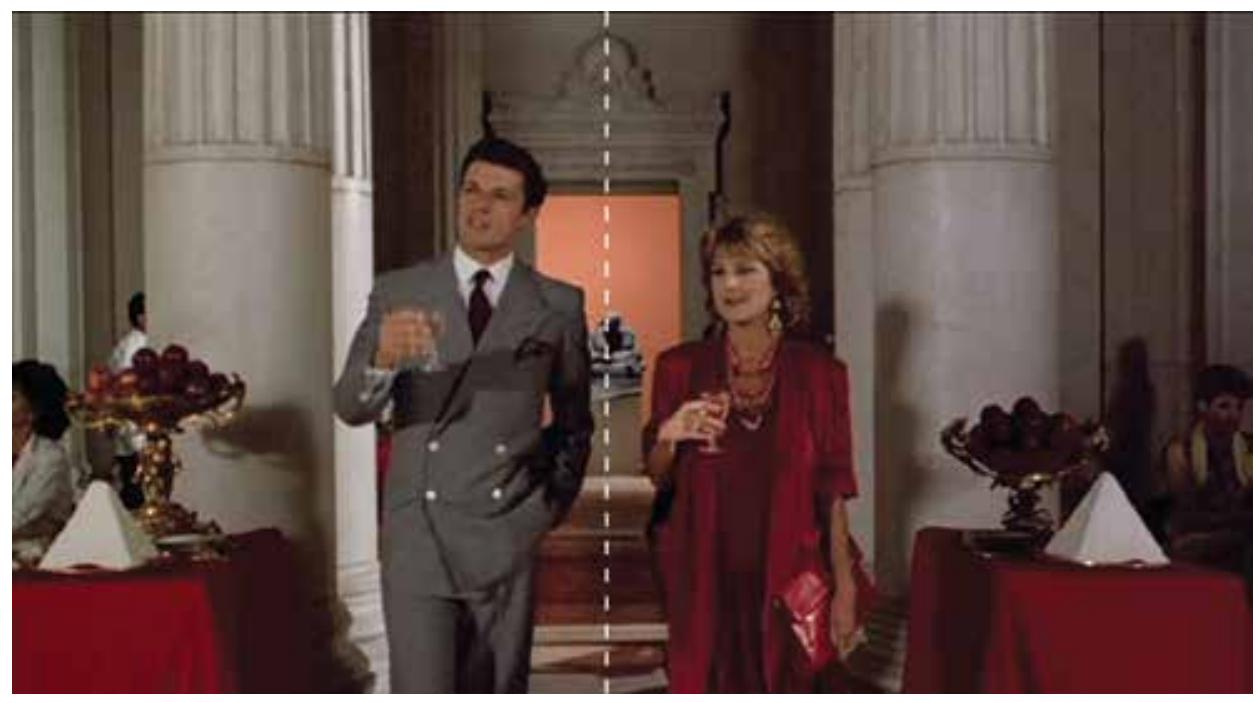

Figura 9: minuto 16:30

"En su camino irrumpirán los Speckler, una familia rival que conspirarán dispuestos a provocar su ruina. Caspasian, el mayor, le disputará no solo el amor de su mujer, también la concesión de un importante proyecto". FUENTE: http://revisordecine.blogspot.com/2014/05/el-vientre-del-arquitecto.html

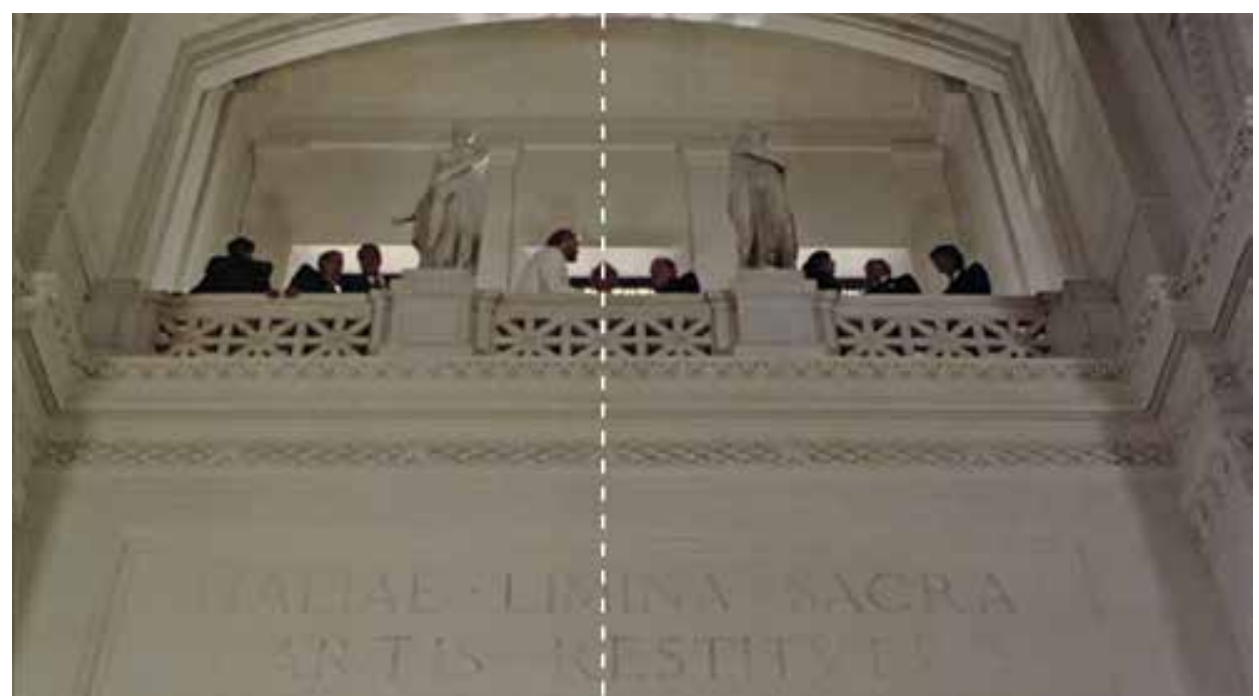

Figura 10: minuto 16:46

En ésta y las dos imágenes anteriores se puede percibir una secuencia rítmica. La cámara acompaña a los personajes y hace un recorrido por el interior del edificio, sin perder el encuadre simétrico. La secuencia termina en una visión en contra picada que es la presente imagen. 


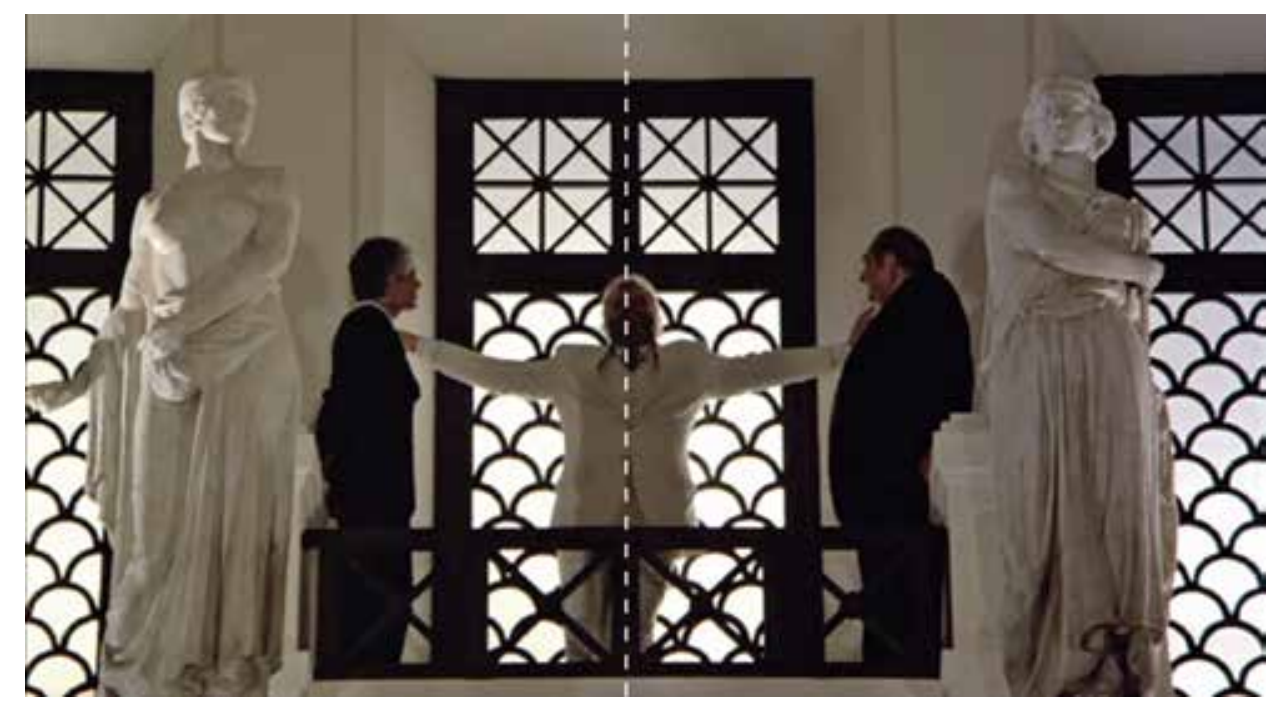

Figura 11: minuto 17:50

La propuesta compositiva involucra a los personajes en la conformación de la simetría, al igual que comparten, los espacios, geográfico y dramático en perfecto equilibrio.

"Al realizar esta composición toma realmente elementos semejantes, primero que todo, de la estructura del comportamiento emocional del hombre, unido con el contenido experimentado de este o aquel fenómeno representado gráficamente". (Eisenstein, 1967, p. 278).

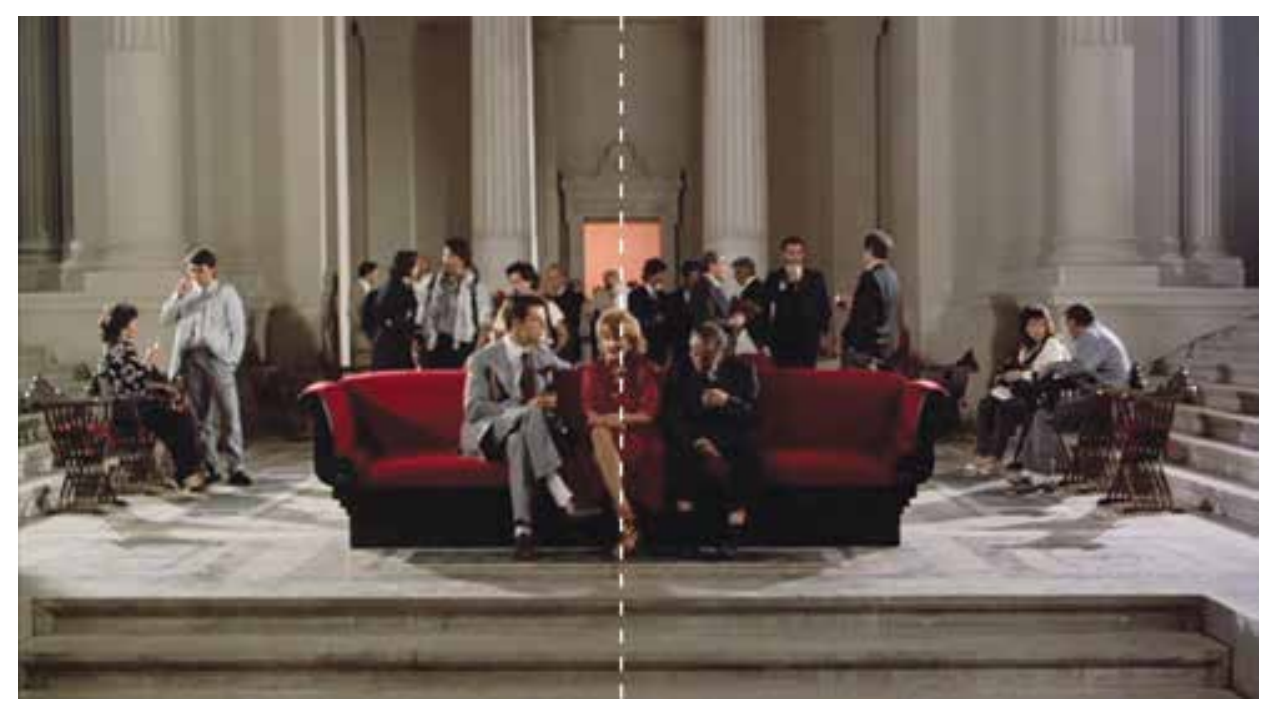

Figura 12: minuto 18:09

El objeto del deseo. ... Y una interesante anomalía. El personaje adulto que se mira sentado en la gran poltrona roja toca la pierna desnuda de la esposa de Kracklite...” Tras la inauguración de la exposición de Boullée, sus socios roban dinero de la exposición, y para más inri, uno de ellos tiene una aventura con su esposa. La serie de desafortunados eventos le provoca el agudo dolor en el vientre al que se hace referencia en el título". FUENTE: http://revisordecine.blogspot.com/2014/05/el-vientre-del-arquitecto.html 


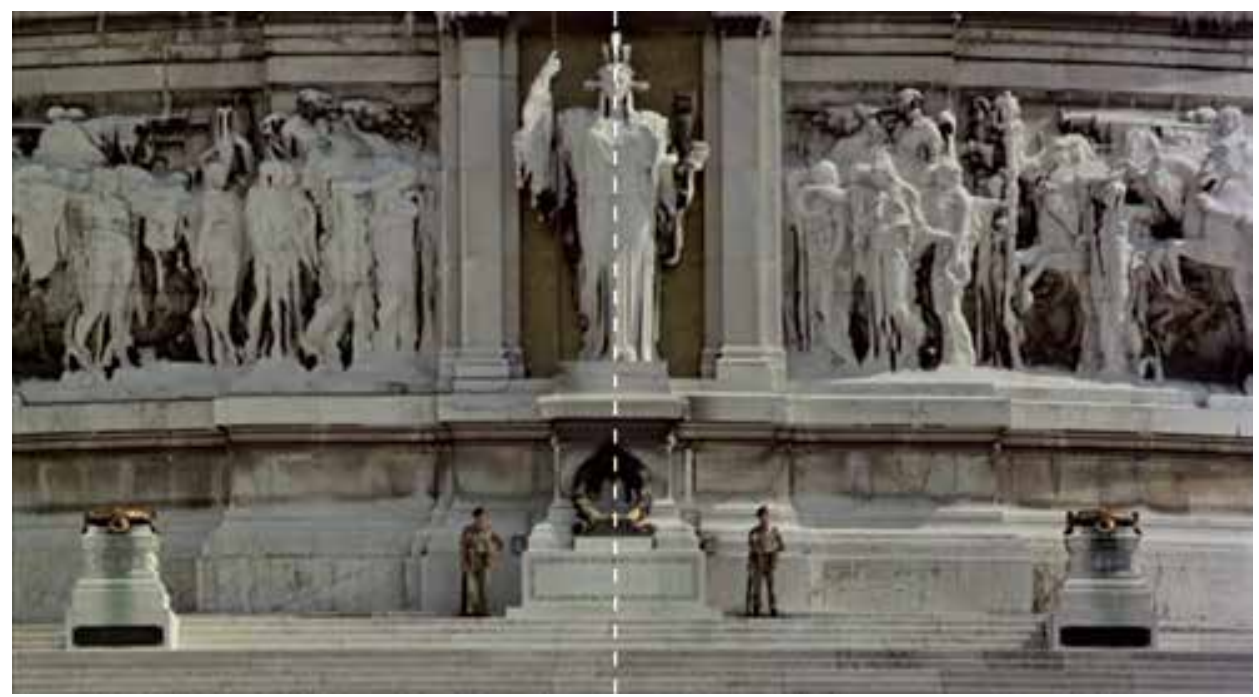

Figura 13: minuto 18:51

"La arquitectura construida por el hombre es la carne visible de una ciudad. Cuando nos paramos frente a una obra arquitectónica no estamos viendo una "cosa". Estamos contemplando la resulta de la dedicación de muchos antepasados. En el intestino humano se concentra la mayor parte de carne humana, preparada para ser convertida en carne de polis. No es de extrañar pues, que para el arquitecto de esta película el vientre suponga una obsesión. La carne es su potencial y su inspiración, y el vientre que a duras penas la alberga es su enfermedad”. FUENTE: http://revisordecine.blogspot.com/2014/05/el-vientre-del-arquitecto. html

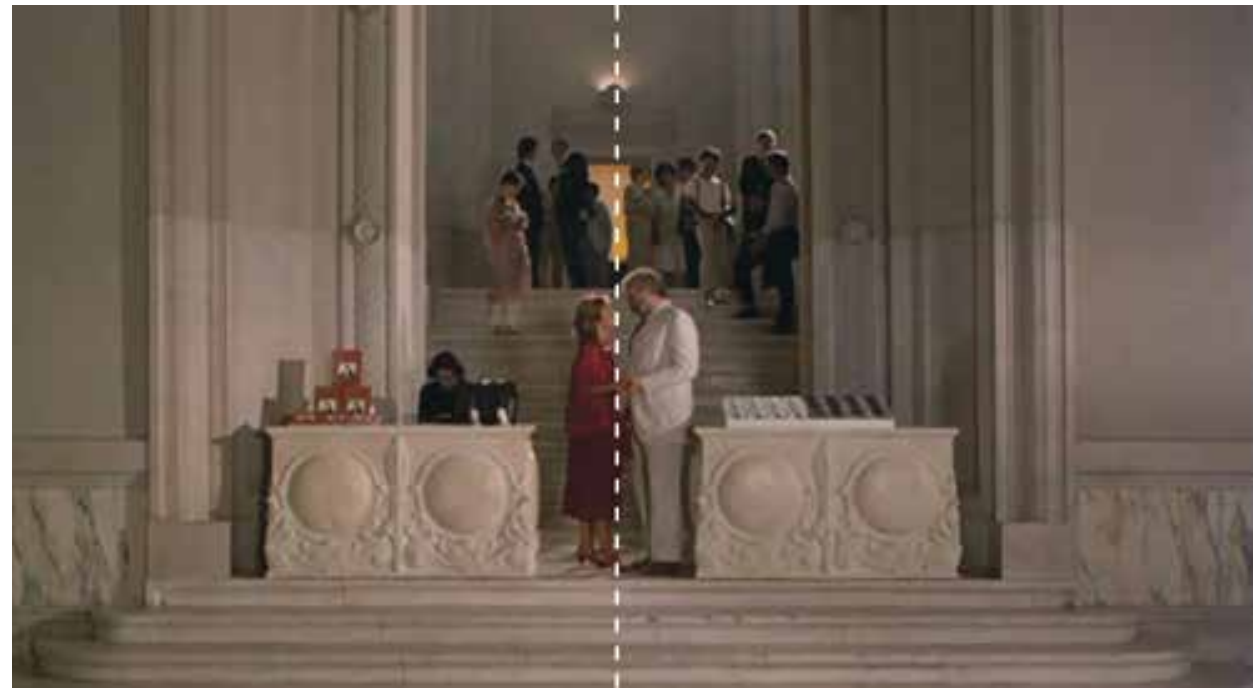

Figura 14: minuto 22:30 


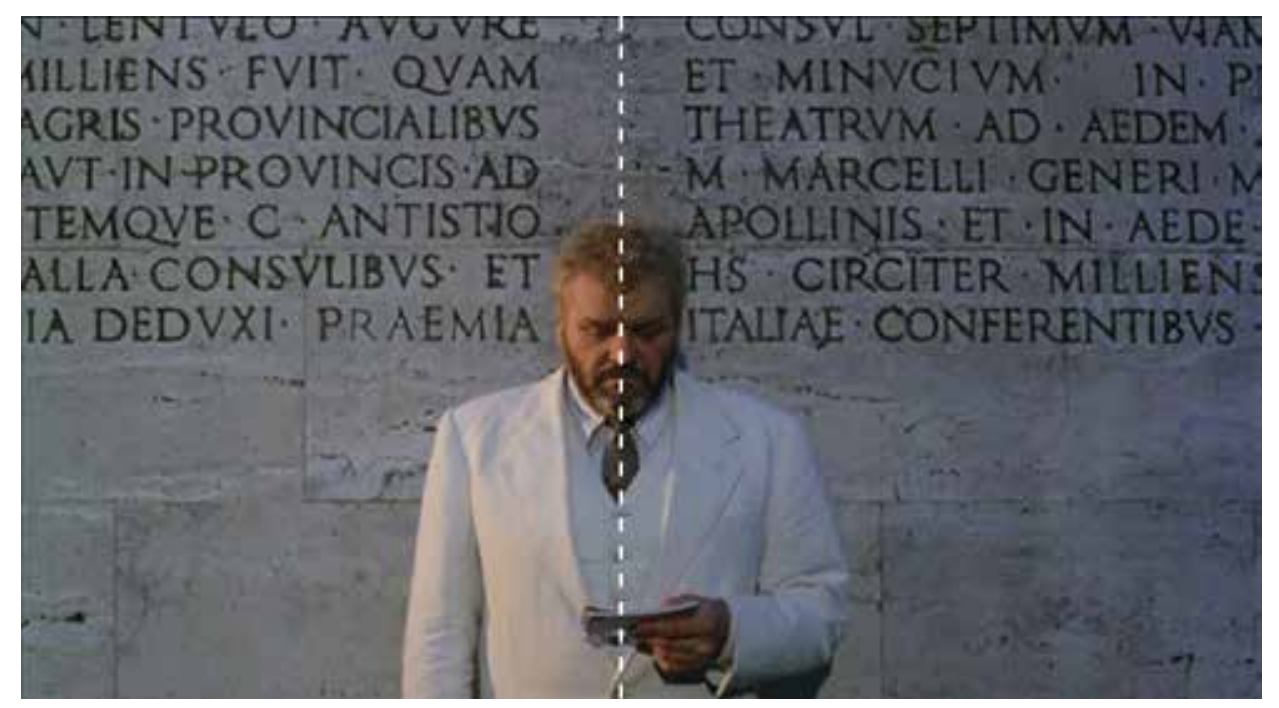

Figura 15: minuto 24:48

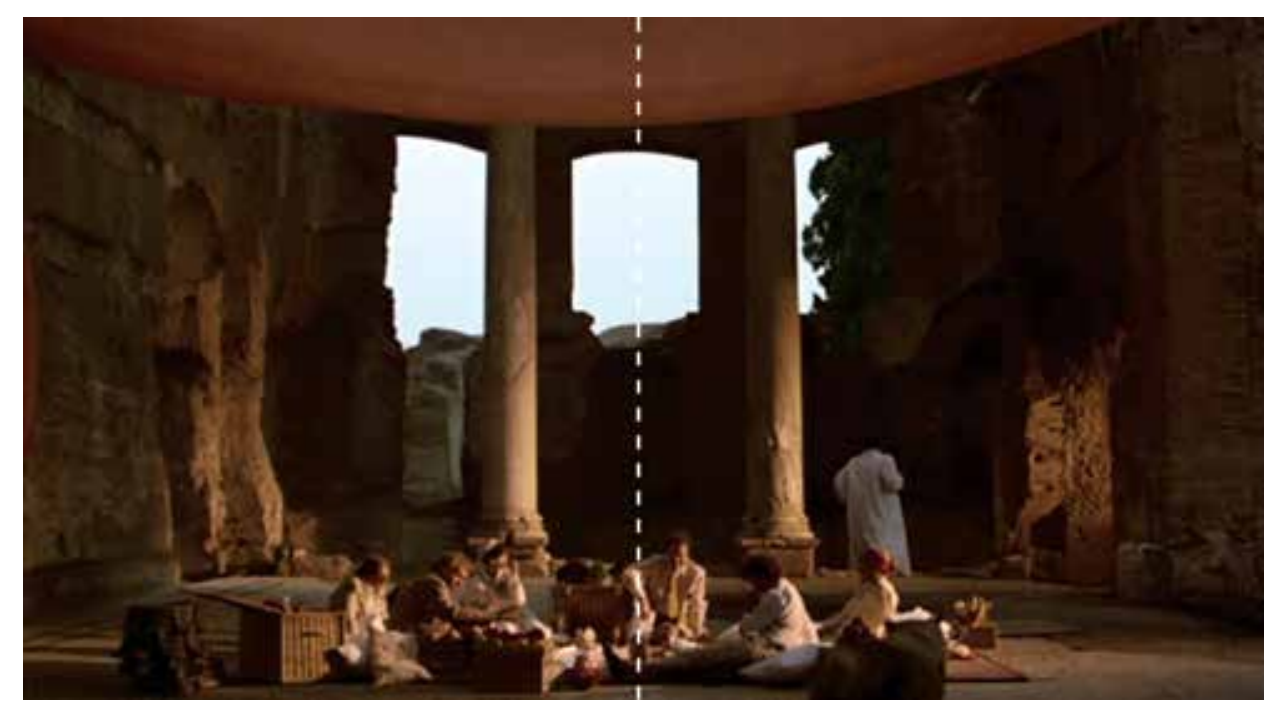

Figura 16: minuto 39:04

..."La composición con ánimo pictórico de los planos está bendecida con el mágico barniz de lo atemporal, los encuadres perfectamente simétricos de enclaves romanos despiertan el sentido del asombro, los reflejos del agua nos sumergen en la melancolía, y la iluminación usando diferentes colores aporta un lúgubre misticismo y riqueza simbólica a un buen número de escenas". FUENTE: http://revisordecine. blogspot.com/2014/05/el-vientre-del-arquitecto.html 


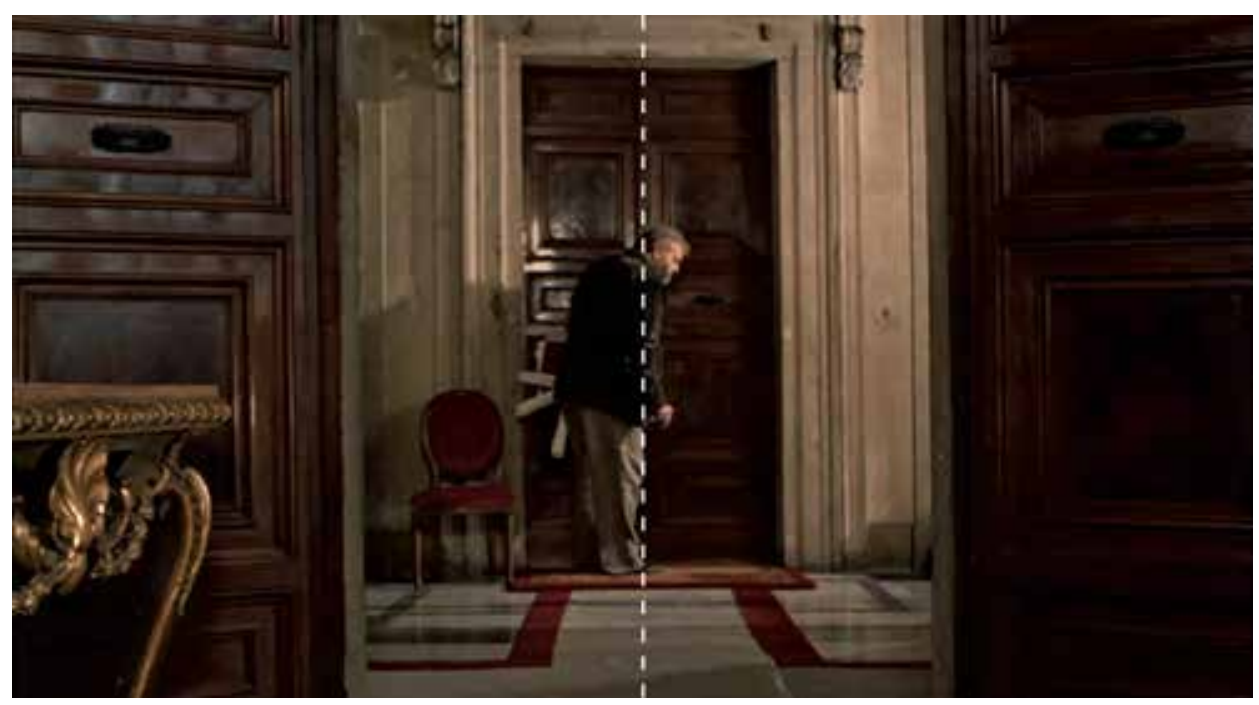

Figura 17: minuto 56:22

Sorpresa y misterio. La agresividad de las puertas cerradas. Más un símbolo.

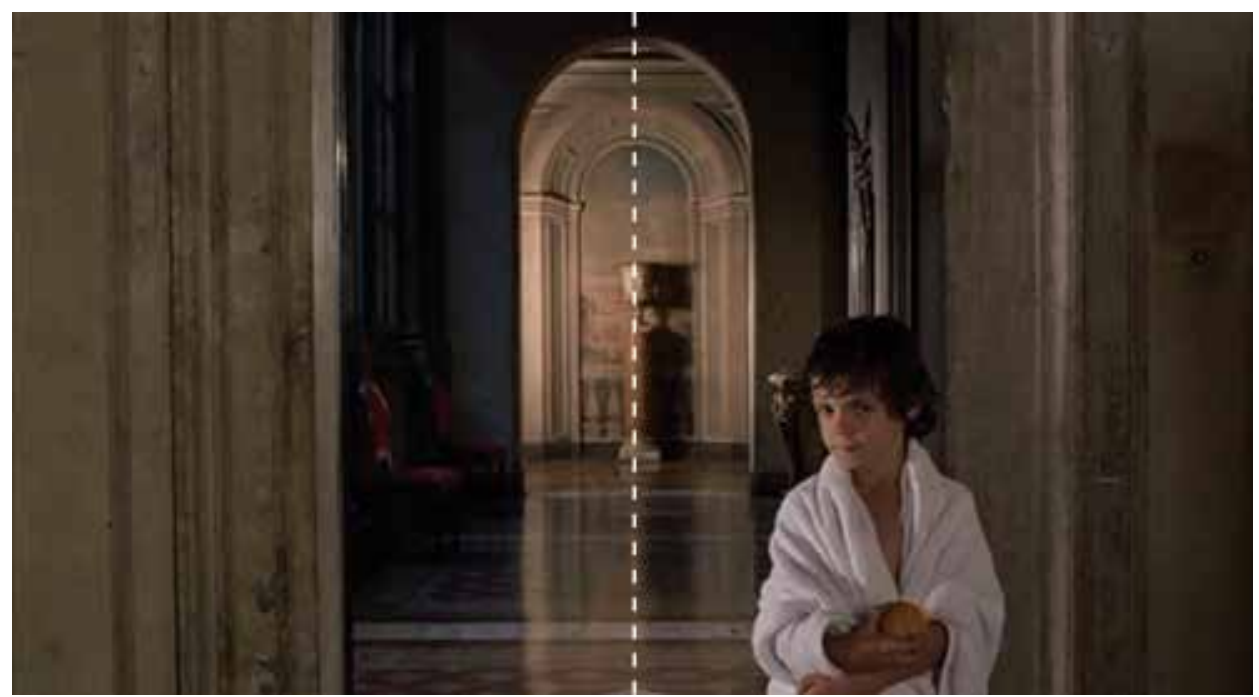

Figura 18: minuto 57:13

Curiosidad, picardía, inocencia... el menudo ser frente al enorme espacio y al conflicto venidero. El juego de los opuestos. 


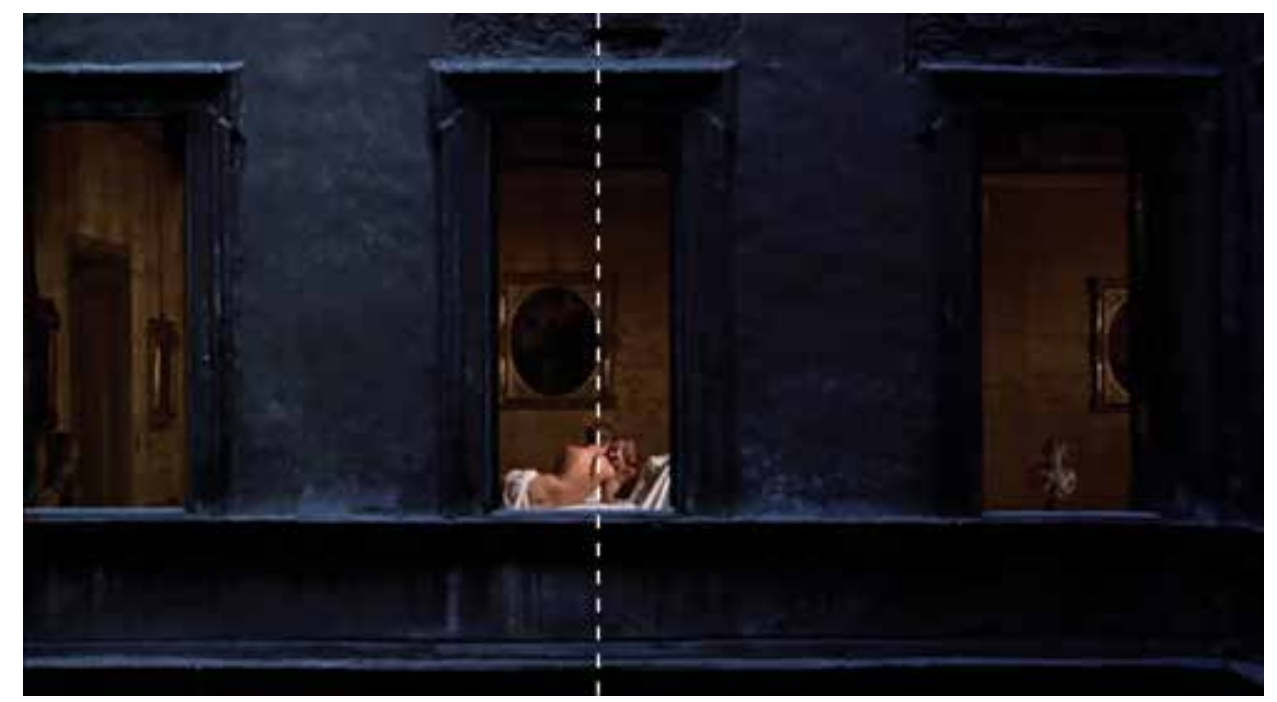

Figura 19: minuto 01:05:25

Deseo, traición, desventura, ¿será la piel culpable?

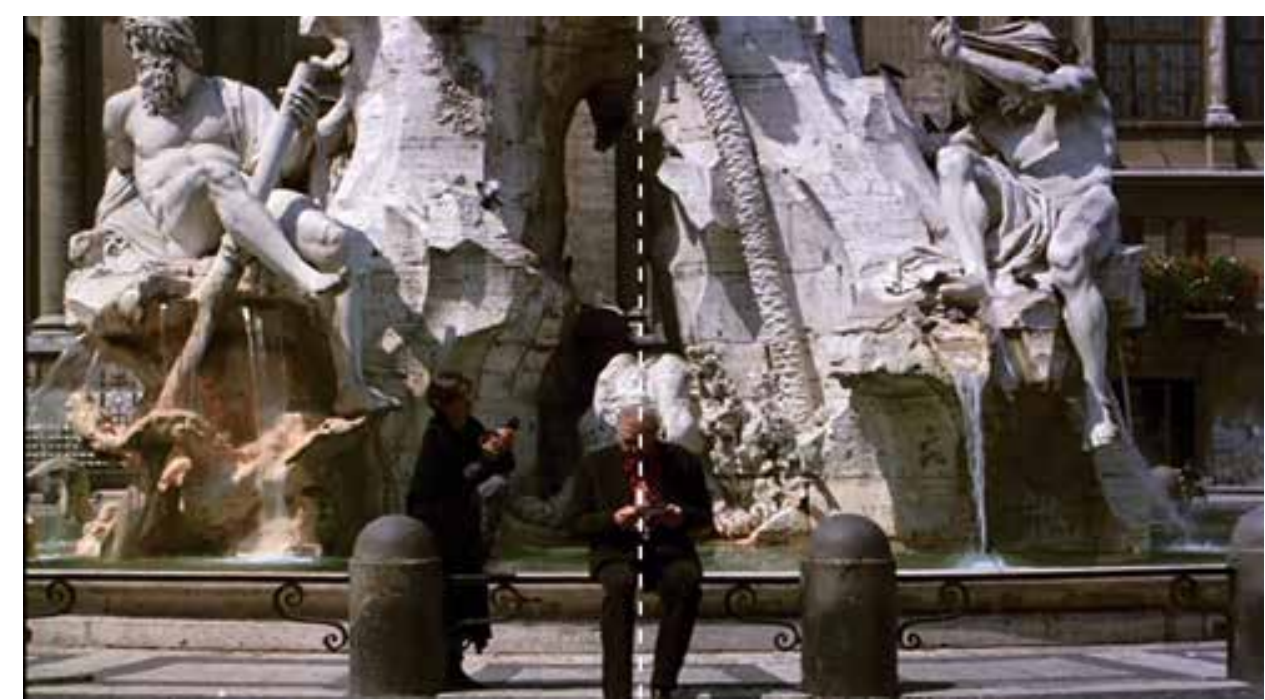

Figura 20: minuto 01:09:51 


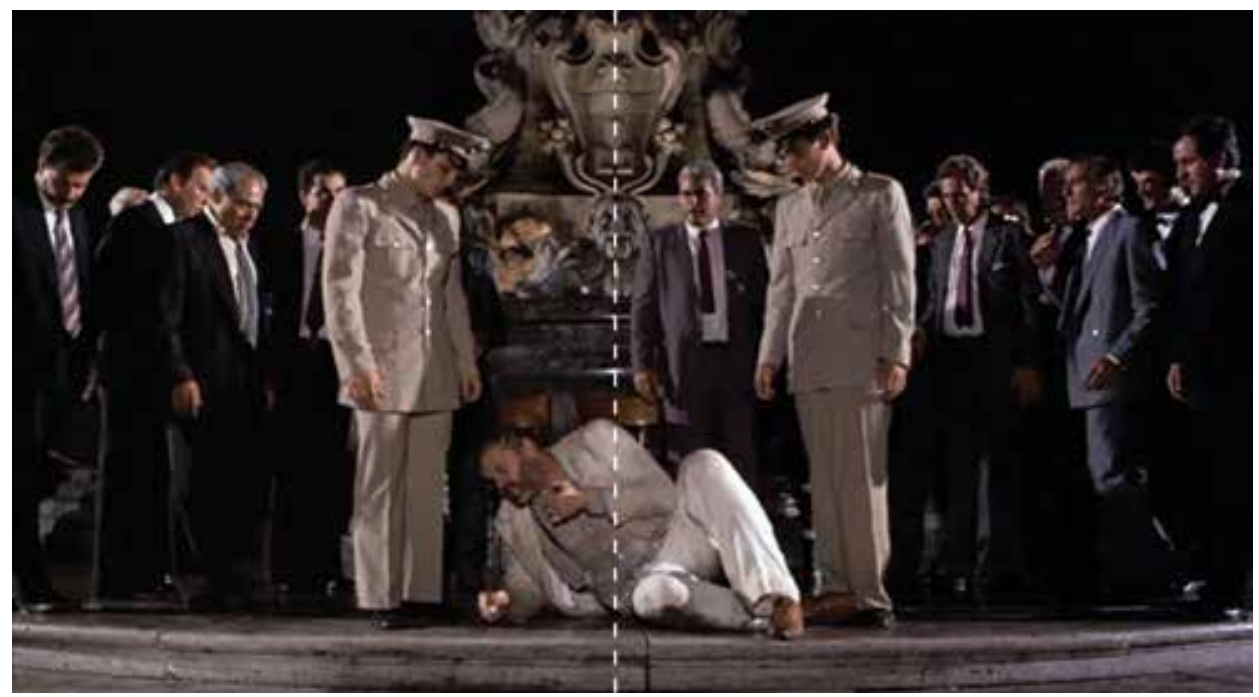

Figura 21: minuto 01:43:45

"Este marco de declive personal sirve a Peter Greenaway para criticar las infraestructuras antiideológicas que sustentan un arte siempre ideológico, la instigada codicia fruto (podrido) del capitalismo, y cómo unos trepas sin talento se llevan la fama y reconocimiento que corresponde a otros mientras estos observan su obra en desesperanzado anonimato". FUENTE: http://revisordecine.blogspot.com/2014/05/ el-vientre-del-arquitecto.html

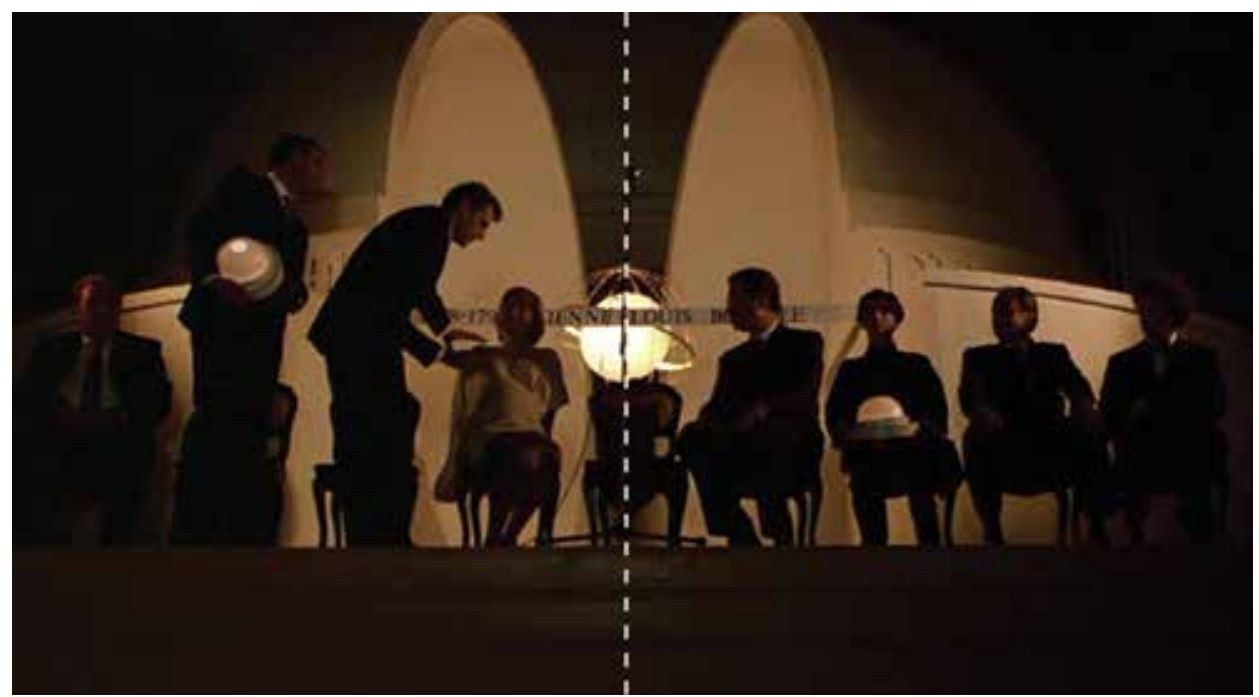

Figura 22: minuto 01:50:37

"Hable en representación de su esposo..." 


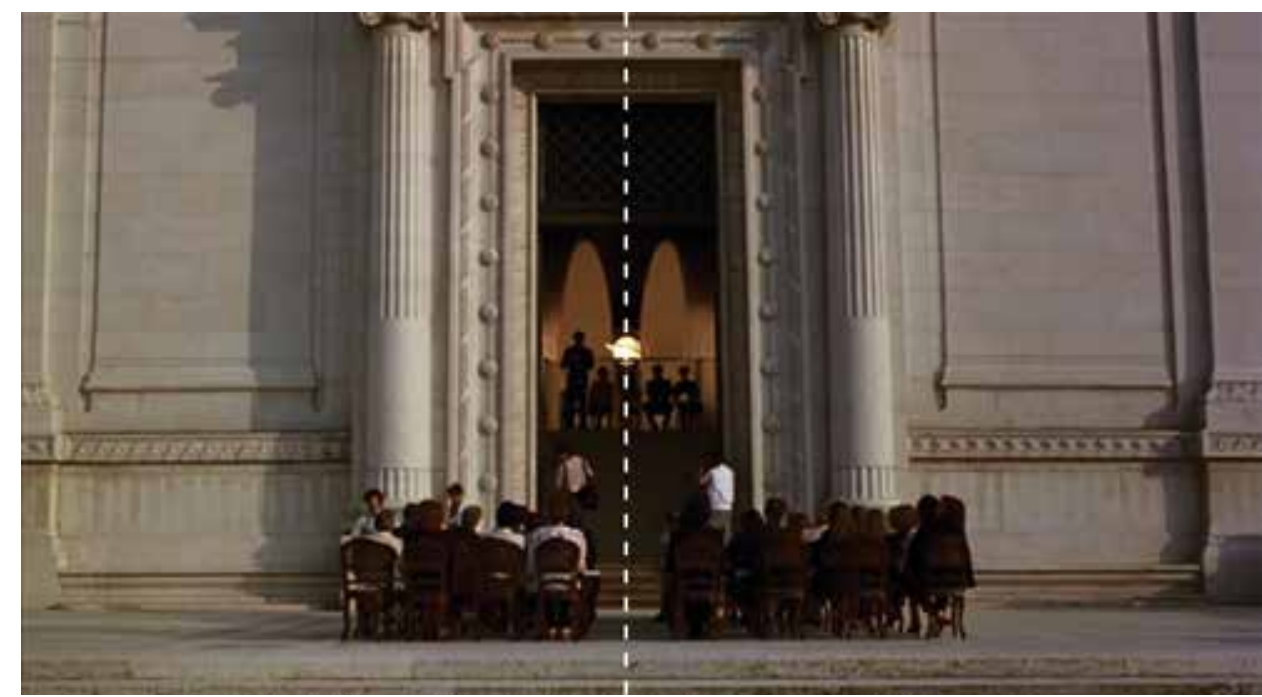

Figura 23: minuto 01:50:52

El evento. Distancia, jerarquía y formalismo, en medio de la pesadumbre...

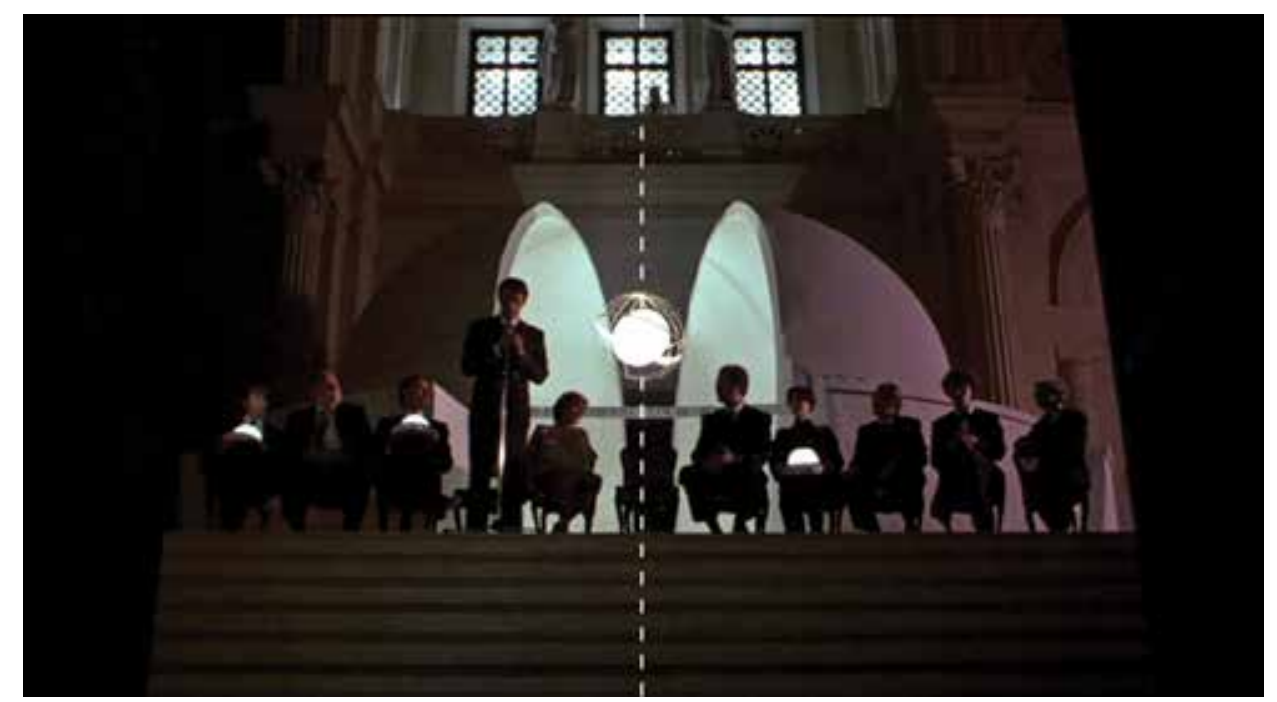

Figura 24: minuto 01:52:54

La ausencia representada... 


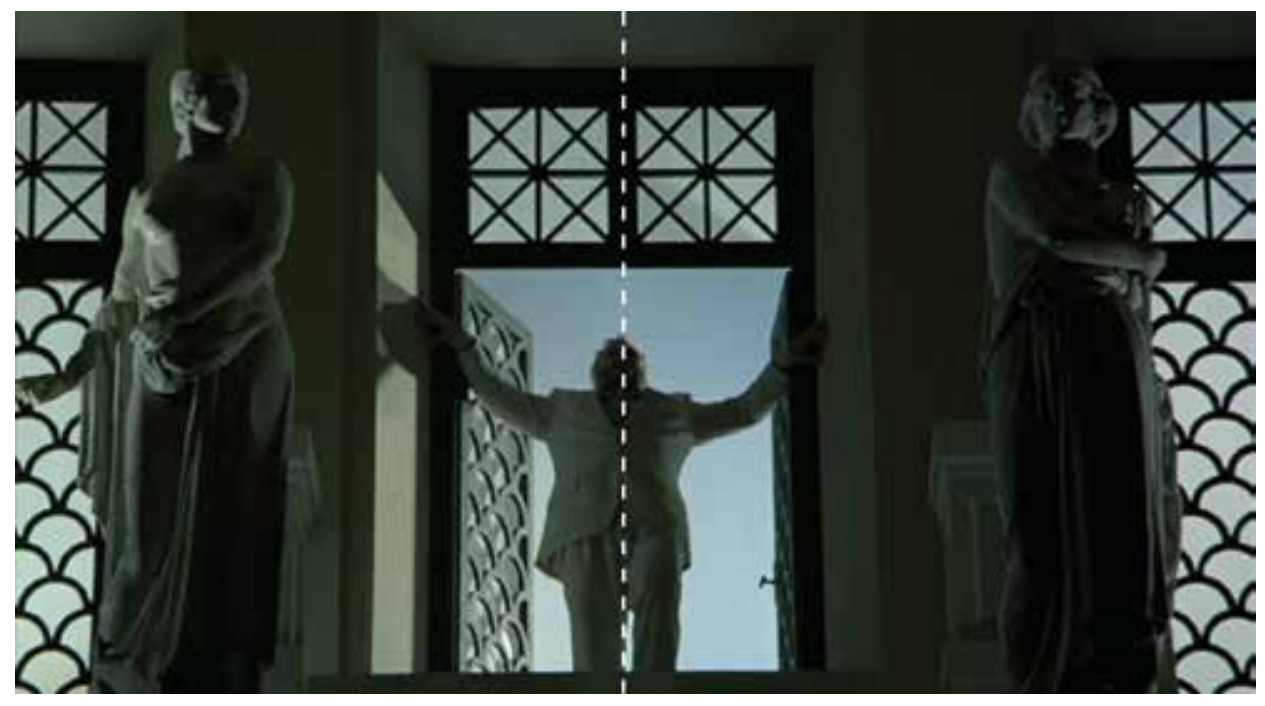

Figura 25: minuto 01:54:32

La ventana posterior se abre y cae de espaldas al vacío...

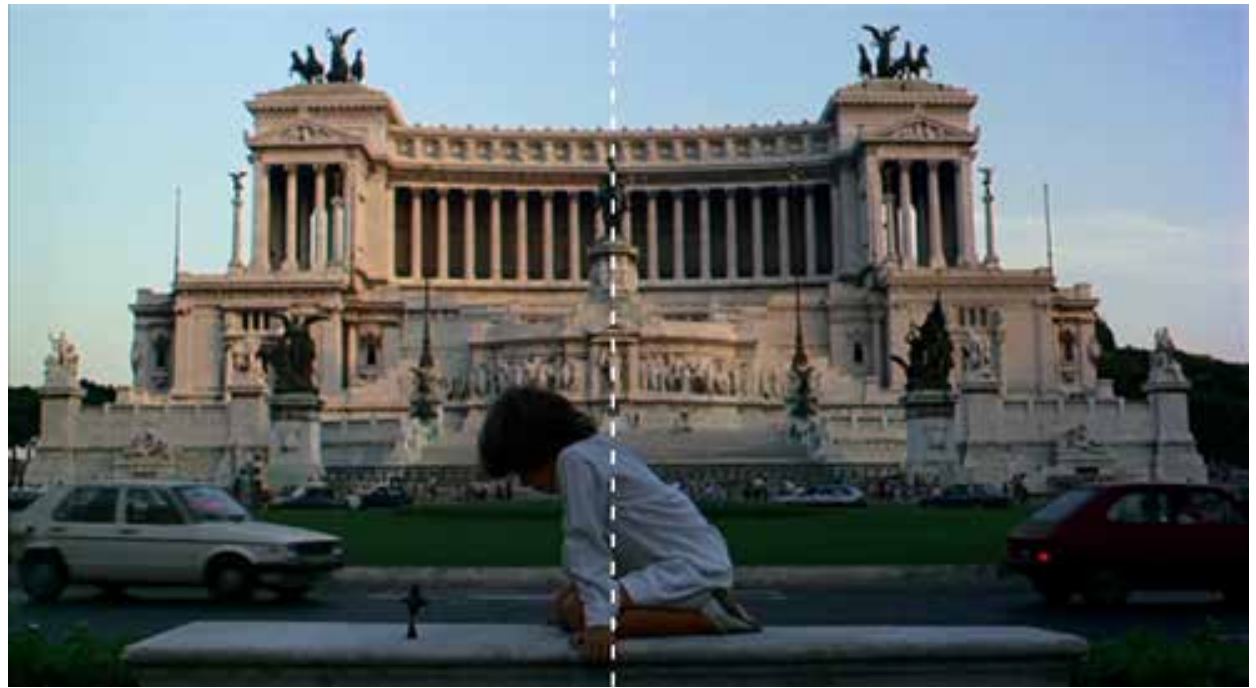

Figura 26: minuto 01:55:15

El personaje con su infancia. Retorno de la vida después de la muerte, se resucita en el propio equilibrio, se trasciende en el mismo ciclo de re_significados... 


\section{Conclusiones:}

¿Que pretende Greenaway en el instante simétrico? De hecho descubrimos una intencionalidad plena como queda dicho, pero también cierta ambigüedad sobre el papel aparente del encuadre. Si bien la evidencia es contundente, resulta muy aventurado afirmar que siempre el recurso se liga con la trama. $\mathrm{Al}$ parecer hay un intento deliberado de anteponer la simetría por sobre todas las cosas, un culto al equilibrio de las formas o quizá, por qué no, la clara superposición de lo aparente con lo representativo. O sea, el mundo de los opuestos en franca y desnuda disputa. El conflicto de los seres humanos, las ansias, los disturbios de la conducta en contraposición con la calma, la armonía y el silencio. En general se diría que este recurso visual, crea un campo escénico sobre el cual se mueve la trama usualmente densa y conflictiva, en un marco riguroso que implica orden y sosiego a la vez.

Greenaway toma los elementos estructurales de una escena y los organiza en función de los acontecimientos para significarlos. La sola descripción del fenómeno no tendría la misma trascendencia si no estuviera ordenado en un marco compositivo simétrico. La imagen es magistralmente dividida con un eje invisible que reproduce a cada lado una escena similar. A su vez, se duplica la acción y el contenido se vuelve superlativo. Como la condición humana expuesta en cada film en que se involucra al hombre con sus mayores emociones.

La tarea es construir el campo significante de la escena. Todo está en perfecta armonía y todo tiene sentido en cuanto cabe todo en el cuadro. Con la simetría se recorta lo accesorio y lo visible tiende a ser valorizado en duplo. Aunque tendría que percibirse, no se siente la descontextualización propia del recorte, ni la desvalorización del extra cuadro, porque la condición simétrica cierra el espacio y lo completa... Y dentro de este momento de momentos la cámara se detiene en el punto matemático pero la acción continúa, para que se inicie el proceso de contemplación.

Dejamos una puerta abierta a todo lo posible, está tendida la mesa, iniciada la frase, dicha la palabra. El mundo de Greenaway abarca más horizontes de los que podríamos imaginar. Tratar de alcanzarlos a todos nos llevaría tiempos alongados, lecturas infinitas....

\section{Bibliografía:}

Almendros, N. Días de una cámara. Barcelona: Editorial Seix Barral, S.A., 1983.

Cartier-Bresson, H. Fotografiar del natural. Barcelona: Editorial Gustavo Gili, SA, 2003.

Eisenstein, S. La forma del cine. La Habana: Ediciones ICAIC, 1967.

Esquinca, J. Las películas indispensables de Peter Greenaway. Artículo digital en la revista Fahrenheit magazine. Enero, 2016. Dirección electrónica:

http://fahrenheitmagazine.com/cultura/ cine/las-peliculas-indispensables-de-petergreenaway/

Flusser, V. Filosofia da caixa preta: ensaios para uma futura filosofia da fotografia. São Paulo: Editora Hucitec, 1985.

Greenaway, P. The belly of an architect. Largometraje de 108 min. Reino Unido, 1987.

Guix, P. La concepción estética en el último cine de 
Peter Greenaway. PDF, en RACO:

ht tp://www.raco.cat/index.php/ FilmhistoriaOnline/article/ viewFile/226913/308535

Libiot, E. Entrevista con Peter Greenaway. Publicación digital en: https://communaute. lexpress.fr/journaliste/eric-libiot

Machado, A. A Ilusão Especular, introdução à fotografia. São Paulo: Editora Brasiliense, 1984.

Mogrovejo Rivera, F. Formas y Organizaciones Bidimensionales. Azuay: Unión Gráfica, 2000.

Vasconcelo Milke, C. Foto Clube do Espirito Santo: A arte fotográfica numa trajetória especifica. Dissertação de Mestrado. Vitória, 2008.

\section{Blogs:}

BLOG Revisor de Cine:

http://revisordecine.blogspot.com/2014/05/elvientre-del-arquitecto.html 